ties, arising from the irregular forms of the oceans, that would choke any attempt at direct dynamical calculation in detail. Other examples of the same faculty are afforded by his fundamental improvements in ships' compasses and in deep-sea sounding; while his life-long work on problems relating to the speed of ships, the waves they produce and the energy lost in their formation, has been a chief influence in the rational study of the conditions and limitations of marine propulsion.

He will be known to future ages, possibly even more widely, as a main pioneer and creator in the all-embracing science of energy, the greatest physical generalisation of the last century. He was the first to grasp and insist on the universal dynamical, even cosmical, importance of the principle of reversible cyclic processes, which sprang almost in advance of its time from the genius of Carnot. Concurrently with Clausius he soon supplied the necessary logical adjustment of its thermal application; and by his own work, and his collaboration with Joule, he largely constructed the practical essentials of the fundamental, because unifying, modern science of thermodynamics. The depth and generality of the conceptions, which pervade his fragmentary and often hurried writings on this subject, have been recognised sometimes only after the same ideas have been slowly evolved afresh, and acclaimed in their varied applications as advances of the first rank, on the part of other investigators.

In Lord Kelvin there has passed away one of the last commanding figures, perhaps in genius and the variety of his activities as great and memorable as any, in the scientific and intellectual development of the nineteenth century.

J. L.

\section{LORD KELVIN AND THE UNIVERSITY OF GLASGOW.}

A $\mathrm{T}$ a college meeting in $\mathrm{I} 89 \mathrm{I}$, Sir William Thomson A said :-" I have been a student of the University of Glasgow fifty-five years to-day, and I hope to continue a student of the Lniversity as long as I live." In 1899 , when he retired from the professorship which he had held for fifty-three years, Lord Kelvin (as he had then become) applied to the Senatus Academicus to be appointed a research student. His name thus remained to the last upon the College roll, and in the list of those who have a right to pursue investigations in the laboratories of natural philosophy.

An academic connection so long, so intimate, and so fruitful is not severed without a deep sense of personal bereavement on the part of the survivors. The university, of which, since 1904, Lord Kelvin was the venerated head, was plunged into deep mourning by the news of his death. Special meetings of the court and senate, and of the executive of the general council, were held, and passed minutes of regret and sympathy. The regular classes were suspended; the courts were silent; the flag that usually waves high over the Kelvin drooped at half-mast. The new institute of natural philosophy which the Chancellor, at its opening in April last, took such pride in displaying to the Prince and Princess of Wales, was closed; and throughout the city, which regards the university's glories as its own, the signs of mourning were everywhere visible. Telegrams and messages from local public bodies, learned societies, and representative men, arrived hourly at Gilmorehill. The note of admiring affection for a great fellow-citizen was prominent in these, for Lord Kelvin was a freeman of the city, and a leader in its technical enterprises, no less than a teacher and investigator in the university. Hence came about a certain wistful acquiescence, on the part of Glasgow men, in the arrangement whereby he was to be laid to rest beside his intellectual peers in Westminster Abbey. The national tribute was felt to be right and fitting; though not a few were hoping that his burying-place would be in the City Necropolis, where his father and others of his kindred are laid.

In order that expression might be given to the genius loci, a memorial service was held by the university in the Bute Hall on Sunday afternoon, December 22, simultaneously with that held at Largs before the funeral company started on their journey southward with Lord Kelvin's body. The hall, which serves as the university chapel, was draped with black, and filled with a congregation of nearly two thousand mourners. All stood, as to the strains of the Dead March the long academic procession, representing the court, senate and other teachers, general council, and students, preceded by the ancient mace swathed in crape, filed in and occupied the stalls and platform. Many of the congregation wore the graduate's robe, and students, men and women alike, wore their undergraduate gowns of scarlet. The ViceChancellor, Principal MacAlister, presided, and read the lessons (Job 28, and I Corinthians 15) from his stall. The simple service of prayer and praise was conducted by two professors of the faculty of divinity (Drs. Reid and Cooper), and was marked by devout resignation, and by thanksgiving for a great example, rather than by the gloom of unrelieved mourning. The anthem Nunc Dimittis, sung by the university voluntary choir, and a special prayer for the university, that in it all science and scholarship might be consecrated to the honour of God and the promotion of human welfare, gave the characteristic notes. There was no sermon or funeral discourse; this will more fittingly be given hereafter. The venerable Lord Blythswood, the Lord Provost, Sir William Bilsland, the president of the faculty of physicians and surgeons, Admiral Bearcroft, Dr. William Wallace, Dr. George Neilson, and many other men of note in the west of Scotland were present. Relatives and others connected with the Chancellor's family, and the officials of the electrical manufacturing firm of Kelvin and White, which he founded, occupied seats near the dais. The funeral march of Chopin closed the ceremony, as the university procession passed out of the hall into the darkness of the winter afternoon, and the silence of the courts that the Chancellor had loved so well.

Telegrams of condolence with the university were received during the week from $\mathrm{Mr}$. Marconi, Glacé Bay; the University of London; University College, Nottingham; the Duke of Argyll, representing $\mathrm{His}$ Majesty the King; the Faculty of Science of the University of Rome: Prof. Egoroff, disector of the Central Chamber of Weights and Measures, St. Petersburg; Principal Voinarowsky, of the St. Petersburg Electrotechnical Institute; the Chancellor of the Exchequer. Lord Rector of the University; Sir James King, Bt., Dean of Faculties; Rector Borgman, of the Imperial University of St. Petersburg; the Russian Physico-chemical Society; Rector Syniewski and professors of the Polish Technical College, Lvov; Rector Bagatcy and professors of the University of Charkow: Rector de Mbinski and Senate of the University of Lemberg; the Royal College of Surgeons of Edinburgh; the Senatus of the U.F. Theological College, Aberdeen; the students of physics of the University of St. Petersburg; President Dini, and the Faculty of Science of the University of Pisa; the University of Liverpool; the Ambassador of France; the Senatus of the University of Aberdeen; the St. Petersburg Society of Electrical Engineers; the pro-rector and professors of the University of Jurjew (Dorpat); \&c.

No. I992, VOL. 77$]$ 